\title{
EFFECT OF SOME FEED ADDITIVES ON PERFORMANCE OF LAYING JAPANESE QUAIL : \\ 1- EFFECT OF MARGORAM LEAVES MEAL AS A FEED ADDITIVE IN LAYING JAPANESE QUAIL DIETS \\ Abd El-Galil, $k$. \\ Animal and Poultry Nutrition Dept., Desert Research Center, Mataria, Cairo, Egypt.
}

\begin{abstract}
A total number of 180 Japanese quail (120 females and 60 males) at 4 weeks of age were used in an experiment lasted 22 weeks. Experimental Japanese quail (Coturnix coturnix japonica) were divided randomly into four equal experimental groups (30 females in each group). The first group was fed the basal diet as control,, while the other three groups were feed additive the Margoram leaves meal (MLM).Margoram leaves meal was added to the control diet at level of $0.5,1.0$ or 1.5 $\mathrm{g} / \mathrm{kg}$ diet, respectively.

The main objective of the present work was to present study was undertaken to establish the utilization of Margoram as medical herbal feed additives in laying Japanese quail diets and their effects on productive performance, nutrient digestibility and economic efficiency. The experimental diets were isocaloric $(2900 \mathrm{kcal} \mathrm{ME} / \mathrm{kg})$, isonitrogenous $(20 \% \mathrm{CP})$ and isofibrous.

Results obtained could be summarized as follows

The final live body weight and body weight change during the whole experimental period varied significantly $(P<0.05)$ increased with increasing $M L M$ levels. The highest live body weight and body weight gain were recorded by using 1.5 and followed by $1 \mathrm{~g} / \mathrm{kg}$, while those fed control diet recorded the lowest ones.

The level of $1 \mathrm{~g} / \mathrm{kg}$ MLM recorded the best values $(P<0.05)$ of feed conversion ratio ( $\mathrm{g}$ feed/g gain), while the control diet recorded the worst feed conversion ratio.

Age at sexual maturity and first egg weight recorded a non-significant difference among groups, while egg weight, egg number and egg mass during the whole experimental period recorded a significant difference $(P<0.05)$ among groups.

It is worthy noting that feed intake $(\mathrm{g} /$ day) increased significantly $(\mathrm{P}<0.05)$ with increasing MLM levels, however $1.5 \mathrm{~g} / \mathrm{kg}$ MLM recorded the highest one.

Feed conversion ratio ( $\mathrm{g}$ feed $/ \mathrm{g}$ egg mass) revealed significantly $(\mathrm{P}<0.05)$ increased with increasing of MLM level in diet, however $1.00 \mathrm{~g} / \mathrm{kg} \mathrm{MLM} \mathrm{recorded} \mathrm{the}$ best feed conversion ratio, while the control diet recorded the worst ones.

Hatchability percentage recorded a non-significant difference among groups.

Albumen, yolk index and egg shape percentage showed significant $(P<0.05)$ increase among the experimental groups, while yolk \% and shell thickness $(\mathrm{mm})$ showed a non-significant decrease between groups.

Digestibility coefficients of OM, CP, CF, EE, NFE and the nutritive values expressed as DCP, TDN \% and ME $(\mathrm{kcal} / \mathrm{kg})$ were significantly varied $(\mathrm{P}<0.05)$ among the different experimental groups.

Level of $1 \mathrm{~g} / \mathrm{kg}$ MLM group showed the best net return as well as the highest value of economic efficiency among experimental groups.

From the nutritional and economical efficiency stand points of view, it could be concluded that, using dietary medical herbal such as Margoram leaves meal (Origanum majorana) at $1 \mathrm{~g} / \mathrm{kg}$ of the diet could improved productive performance and economical efficiency of laying Japanese quail.
\end{abstract}

Keywords: Quail, Margoram leaves meal, productive performance, egg quality, digestibility and economical efficiency. 


\section{INTRODUCTION}

Many attempts have been made by nutritionists for to improve the productive performance and feed utilization in order to reduce the cost of feeding by using dietary additives such as antibiotics, probiotics, enzymes and herbal medicinal plants.

Recently, many countries tended to prohibit the using of antibiotics as growth promoters because of their side effect on both birds and human health.

The recent studies have showed that medicinal plants can be used instead of chemical compounds in poultry diets as natural tonic, restoratives (Boulos, 1983), antibacterial and antiparasitic drugs (khodary et al., 1996) to obtain the best performance parameters, immunity and the viability of birds (El- Hindawy et at., 1996 and Osman, 1996).

Addition of herbal parts and plant seeds as natural feed additives improved productive performance of poultry (Abdel-Aal and Attia, 1993); Khodary et al.(1996), Gill (1999) and Abaza (2001).

Medicinal plants have been reported to have health benefit properties and their preventive and therapeutic use in poultry is expected to increase in the future and a numerically large group of economically important plants.

The natural feed additives as the medicinal plants such as Margoram (Origanum majorana) leaves meal are a numerically large group of economically important plants, the include various species, which are used in the treatment of various diseases in human. This plant not only serves for a medicinal purpose but also contain aromatic substances and essential oils that used in food industries for human. Marjoram is useful oil for several ailments impacting on the immune system.

The genus Origanum (Lamiaceae) is an annual, perennial and shrubby herb that is native to the Mediterranean, Euro-Siberian and IranoSiberian regions. A total of 38 Origanum species are recognized in the world. Most of the Origanum species, over $75 \%$, are concentrated in the East Mediterranean (Souad El-Gengaihi et al., 2006)

Origanum was determined. Antioxidant and antibacterial activities of the isolated essential oils, the oils of oregano plants were strongly characterized by p-cymene $(16.80 \%)$, gamma-terpinene $(16.80 \%)$,thymol $(8.40 \%)$, and carvacrol $(1.10 \%)$, all essential oils possessed antioxidant activity( Hazzit et al., 2006).

Origanum majorana is a potent antioxidant, significantly reduced number of gaps, ring chromosome and stickiness, and plays an important role in ameliorating liver and kidney functions and genotoxicity (El-Ashmawy 2005).

All essential oils exhibited a very strong antibacterial activity against the tested bacteria $(\mathrm{P}<0.05)$, analyses revealed that carvacrol $(68.23 \%), 1,8$ cineole $(60.72 \%)$,fenchone (55.79\%)and trans-anethole (85.63\%) (Dadaliog and Evrendilek, 2004)

The essential oil has proven powerful anti-infectious properties against bacteria, fungi and viruses. Additionally, it has a tonic action and 
supposed to be of immune system. These properties are mainly due to the essential oils phenolic content, namely thymol and carvacrol 47-48\%, respectively.

Origanum majorana induced a significant decrease in serum activities of transaminases (AST \& ALT), ALP, urea and creatinine and improved the liver and kidney. Volatile oil extract significantly reduced the rate of micronucleus and chromosomal fragments. Also significantly reduced number of gaps, ring chromosome and stickiness. It could be concluded that $O$. majorana plays an important role in ameliorating liver and kidney functions and genotoxicity.

The major Fatty acids of Origanum species were linolenic (56.3$57.0 \%$; linoleic $(21.5-21.7 \%)$, oleic $(8.7-8.9 \%)$, palmitic $(5.9-6.5 \%)$, stearic (2.1-2.4\%) and 11-octadecenoic (0.6-0.8\%), (Azcan et al., 2004)

Margoram as a medicinal herbal there is a general agreement using natural feed additives as the medicinal plants improved performance and health and immunity of poultry.

Abd EL-Latif et al.(2003) who found that the Margoram addition to the diets of growing Japanese at levels $0.5 \%$ diets improved of growth performance.

So, The main objective of the present work was to present study was undertaken to establish the utilization of Margoram (Origanum majorana) leaves meal as a feed additive (medical herbal) in laying Japanese quail diets and their effects on reproductive performance, nutrient digestibility and economic efficiency.

\section{MATERIALS AND METHODS}

The present experiment was carried out at Maryiout Experimental Research Station (South West of Alexandria), which belongs to the Desert Research Center. A total number of 180 Japanese quail (120 females and 60 males) at 4 weeks of age were used in an experiment lasted 22 weeks. Experimental Japanese quail (Coturnix coturnix japonica) were kept under similar managerial, hygienic and environmental conditions and were divided randomly into four equal experimental groups (30 females in each group).

Quail were kept in batteries, which were divided into separate cages, where two females were housed in each cage. The first group was fed the basal diet as control $(0 \% \mathrm{MLM})$, while the other three groups were feed additive the Margoram leaves meal (MLM). Margoram leaves meal (Origanum majorana) was added to the control diet at level of $0.5,1.0$ or $1.5 \mathrm{~g} / \mathrm{kg}$, respectively.

The quail were housed in cages at 4 weeks till 22 weeks of age. The experimental diets (Table 1) were formulated according to N.R.C (1994) and were isonitrogenous (20\% crude protein) and isocaloric (2900 kcal ME/kg). Feed and water were available ad libitum. Chemical analysis of the experimental diet and dried excreta were assayed using methods of A.O.A.C (1990). 
Table(1). Composition and proximate chemical of basal diet.

\begin{tabular}{|c|c|}
\hline Ingredients & $\%$ \\
\hline Yellow corn & 60.00 \\
\hline Soybean meal (44\% CP) & 5.38 \\
\hline Concentrate $(52 \% \mathrm{CP})^{*}$ & 10.00 \\
\hline Corn gluten meal $(60 \% \mathrm{CP})$ & 10.00 \\
\hline Wheat bran & 9.10 \\
\hline Dicalcium phosphate & 0.50 \\
\hline Limestone ground & 4.30 \\
\hline Vit. and min. premix ${ }^{\star \star}$ & 0.30 \\
\hline L-lysine & 0.20 \\
\hline DI- methionine & 0.22 \\
\hline Total & 100 \\
\hline \multicolumn{2}{|l|}{ Proximate chemical analysis \% } \\
\hline Crude protein & 20.25 \\
\hline Crude fiber & 3.37 \\
\hline Ether extract & 3.81 \\
\hline \multicolumn{2}{|l|}{ Calculated values } \\
\hline Metabolizable energy $(\mathrm{kcal} / \mathrm{kg})^{\star \star *}$ & 2900 \\
\hline Calcium \% & 2.51 \\
\hline Available phosphorus \% & 0.30 \\
\hline Methionine \% & 0.46 \\
\hline Lysine \% & 1.00 \\
\hline Methionine + Cystin \% & 0.70 \\
\hline Price /k diet L.E. ${ }^{* * *}$ & 1.350 \\
\hline
\end{tabular}

* Protein concentrate contained, $52 \%$ Crude protein, 2.03\% Crude fiber, 6.17\% Ether extract, ME $2800(\mathrm{kcal} / \mathrm{kg}), 1.50 \%$ Methionine, 2.0\% Methionine \& Cystln, 3.0\%Lyslne 7.00\% Calcium, $2.93 \%$ Available Phosphorus $2.20 \%$ Nacl.

** Each $3 \mathrm{~kg}$ Vitamins and minerals premix contains (per ton of feed), Vit. A $10000000 \mathrm{IU}$, Vit. D3 2000000 IU, Vit.E I0g, Vit.K3 1000 mg, Vit. B1 1000 mg, Vit. B2 5g, Vit. B6 1.5g, Vit. B12 $10 \mathrm{mg}$, Pantothenic acid $10 \mathrm{~g}$, Niacin $30 \mathrm{~g}$, Folic acid $1 \mathrm{~g}$, Biotin $50 \mathrm{mg}$, Iron $30 \mathrm{~g}$, Manganese $70 \mathrm{~g}$, Choline chlorite $10 \mathrm{~g}$, lodine $300 \mathrm{mg}$, Copper $4 \mathrm{~g}$, Zinc $50 \mathrm{~g}$ and Selenium $100 \mathrm{mg}$.

${ }_{* \star \star}$ Calculated according to NRC of poultry (1994).

${ }^{\star \star \star \star}$ Calculated according to price of feed ingredients at the same time (2006) of the experiment. Price of one $\mathrm{kg} \mathrm{MLM=14.00} \mathrm{L.E.}$

During the experimental period, individual live body weight and feed intake were determined biweekly. Feed conversion ratio ( $\mathrm{g}$ feed intake / $\mathrm{g}$ egg mass) was calculated and the mortality was recorded every day.

Age at sexual maturity was determined at the first egg laying. Eggs were collected daily and weighed for each group, so egg number, egg mass were calculated during the experimental period. At 15 weeks of age, 20 eggs were randomly taken from each group and were used to evaluate egg quality; yolk weight and shell weight were recorded. Shell thickness (without membrane) was measured by micrometer, while albumen weight was calculated by subtracting yolk and shell weight from egg weight, Yolk, shell and albumen percentage were calculated as a percentage of egg weight.

Males were housed individually in cages (one quail per cage) and fed the same diets for females. At 15 weeks of age, males (40 males) were 
transferred to female cages (two females and one male) for twenty minutes for five days, the eggs were then collected and incubated. Hatchability percentage was calculated for each group.

At the end of the experimental feeding period, digestion trials were conducted using 20 adult quail males (five quail from each treatment) to determine the digestibility coefficients and the nutritive values of the experimental diets as affected by MLM levels. Males were housed individually in metabolic cages.

The digestibility trials extended for 9 days of them 5 days as a preliminary period followed by 4 days as collection period. The individual live body weights were recorded during the main collection period to determine any loss or gain in the live body weights. During the main period, excreta were collected daily and weighed dried at $60^{\circ} \mathrm{C}$ bulked finally ground and stored for chemical analysis. The faecal nitrogen was determined according to Jakobsen et al.(1960). Urinary organic matter was calculated according to Abou-Raya and Galal (1971). Metabolizable energy was calculated according to Titus and Fritz (1971).

The digestion coefficients \% of organic matter (OM), crude protein (CP), crude fiber (CF), ether extract (EE) and nitrogen free extract (NFE) of the experimental diets were estimated.

The nutritive values expressed as digestible crude protein (DCP), total digestible nutrients (TDN) and metabolizable energy (ME) were calculated.

Economical efficiency for egg production was calculated from the input / output analysis according to the costs of the experimental diets and selling price of one $\mathrm{kg}$ egg. The values of economical efficiency were calculated as the net revenue per unit of total costs.

Statistical analysis was carried out using General Linear Model (GLM) procedures by SAS program (1996) using simple one way analysis of variance according to this model:

Where:

$$
Y_{i j}=\mu+T_{i}+e_{i j}
$$

$Y_{i j}=$ Represented observation in $j^{\text {th }}$ Margoram leaves meal.

$\mu=$ Overall mean.

$T_{i}=$ Effect of $j^{\text {th }}$ Margoram leaves meal level $(j=0,0 \cdot 5,1 \cdot 0,1 \cdot 5 \mathrm{~g})$.

$\mathrm{e}_{\mathrm{ij}}=$ Random error.

Duncan's New Multiple Range Test (Duncan, 1955) separated differences among treatment means.

\section{RESULTS AND DISCUSSION}

\section{Live body weight and body weight change}

Data for live body weight and body weight change during the whole experimental period by quail females is summarized in table 2 . The final live body weight and body weight change during the whole experimental period varied significantly $(P<0.05)$ among the experimental groups.

It is worthy noting that live body weight was improved with increasing the MLM level in the diet, is gradually fed diets supplemented with MLM on 
Abd EI - Galil, $k$.

$1.5 \mathrm{~g} / \mathrm{kg}$ MLM recorded $2.23 \%$ higher than that of the control group, while 1.0 or $0.5 \mathrm{~g} / \mathrm{kg} \mathrm{MLM}$ resulted in 2.04 and $1.44 \%$ higher than that of the control group, respectively.

Live body weight change during the whole experimental period, It is clear that Live body weight change during the whole experimental period was increased by increasing MLM levels in the experimental diets.

The supplementation with $0.5,1.0$ or $1.5 \mathrm{~g} / \mathrm{kg}$ MLM level increased live body weight change by $2.27,4.22$ and $4.36 \%$ more than that of the control group, respectively.

Table (2). The productive performance ( $\bar{X} \pm S E$ ) of laying quail as affected by dietary Margoram leaves meal supplementation.

\begin{tabular}{|c|c|c|c|c|c|}
\hline \multirow{2}{*}{ Items } & \multicolumn{4}{|c|}{ Levels of margoram leaves meal $(\mathrm{g} / \mathrm{kg})$} & \multirow{2}{*}{ Sig } \\
\hline & Control (0) & 0.5 & 1.00 & 1.50 & \\
\hline $\begin{array}{lll}\text { Initial live } & \text { bod } \\
\text { weight }(\mathrm{g}) & \\
\end{array}$ & $116.52 \pm 5.4 \mid$ & $117.06 \pm 5.07$ & $115.95 \pm 5.01$ & $116.22 \pm 5.51$ & ns \\
\hline $\begin{array}{l}\text { Final live body } \\
\text { weight }(\mathrm{g})\end{array}$ & $252.10+3.41^{b}$ & $255.72+3.65^{\mathrm{ab}}$ & $257.25+4.61^{\mathrm{a}}$ & $257.71+4.21^{a}$ & * \\
\hline $\begin{array}{l}\text { Live body weight } \\
\text { change }(\mathrm{g})\end{array}$ & $135.58 \pm 1.06^{b}$ & $138.66 \pm 1.91^{\mathrm{ab}}$ & $141.30+2.02^{a}$ & $141.49+2.51^{\mathrm{a}}$ & * \\
\hline $\begin{array}{l}\text { Age at sexual } \\
\text { maturity/bird/day }\end{array}$ & $49.23 \pm 0.16$ & $49.11 \pm 0.17$ & $49.00 \pm 0.22$ & $49.00 \pm 0.27$ & ns \\
\hline $\begin{array}{l}\text { First egg weight } \\
(\mathrm{g}) \text {. }\end{array}$ & $11.60 \pm 0.19$ & $11.62 \pm 0.11$ & $11.65+0.15$ & $11.65+0.18$ & ns \\
\hline Egg weight $(g)$ & $11.51 \pm 0.12^{\mathrm{b}}$ & $11.55 \pm 0.10^{\mathrm{ab}}$ & $11.64 \pm 0.12^{\mathrm{a}}$ & $11.62 \pm 0.15^{\mathrm{a}}$ & 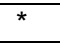 \\
\hline $\begin{array}{l}\text { Egg number/ } \\
\text { bird/day }\end{array}$ & $0.60 \pm 0.03^{b}$ & $0.65 \pm 0.05^{\mathrm{ab}}$ & $0.67 \pm 0.06^{a}$ & $0.67 \pm 0.03^{a}$ & * \\
\hline $\begin{array}{|ll|}\text { Egg mass }(\mathrm{g}) / \\
\text { bird/day }\end{array}$ & $6.91 \pm 0.15^{b}$ & $7.51 \pm 0.21^{\mathrm{ab}}$ & $7.79 \pm 0.18^{\mathrm{a}}$ & $7.77 \pm 0.19^{a}$ & * \\
\hline $\begin{array}{l}\text { Feed intake }(\mathrm{g}) / \\
\text { bird/day }\end{array}$ & $29.01 \pm 0.36^{\mathrm{b}}$ & $29.55 \pm 0.32^{\mathrm{ab}}$ & $29.91 \pm 0.15^{\mathrm{a}}$ & $30.41 \pm 0.27^{a}$ & * \\
\hline $\begin{array}{l}\text { Feed conversion } \\
\text { ratio }\end{array}$ & $4.20 \pm 0.09^{a}$ & $3.93+0.10^{\mathrm{a}}$ & $3.78 \pm 0.07^{b}$ & $3.91 \pm 0.12^{\mathrm{a}}$ & * \\
\hline Morality rate \% & 0.00 & 0.00 & 0.00 & 0.00 & \\
\hline Hatchability \% & $79.02 \pm 5.82$ & $79.20 \pm 9.20$ & $79.25 \pm 10.21$ & $79.22 \pm 10.51$ & ns \\
\hline
\end{tabular}

a.b: Means within a row with different superscripts are significantly different.

Sig. $=$ Significance, ${ }^{*}=(P<0.05)$, n.s $=$ not significant.

The increase in body weight change reflected may be due to the increase in feed intake and the improvement in nutrients digestibility of diets. This positive effect may be attributed to the biological function of medical plant components that have been essential for growth (Boulos, 1983; Bradley, 1992; Leung and Foster, 1996). Ibrahim et al. (1998) who reported that adding natural additives in broiler diets caused a significant increase in broiler performance. Bachman and Mashaly (1986) the improvement in the performance due to enhancement in thyroid activity.

\section{Age at sexual maturity}

Sexual maturity age ranged from 49.22 to 49.88 day, showing that MLM levels in laying quail diets did not affect this trait as shown in table (2). 


\section{Weight of first egg}

Results of first egg weight were found to be statistically insignificant as shown in table 2. It is worthy noting that feeding quail on 1.0 and $1.5 \mathrm{~g} / \mathrm{kg}$ of MLM recorded slight higher values compared to other experimental groups.

\section{Egg weight}

Egg weight during the whole experimental period differs significantly $(\mathrm{P}<0.05)$ among the experimental groups. It is worth noting that Supplementation of diet by $0.5,1.0$ or $1.5 \mathrm{~g} / \mathrm{kg}$ of MLM recorded an increase in egg weight amounted to $0.35,1.13$ or $0.96 \%$ compared to the control group, respectively.

Level of $0.5 \mathrm{~g} / \mathrm{kg}$ MLM recorded the lowest egg weight $(11.55 \mathrm{~g})$, while Level of $1.00 \mathrm{~g} / \mathrm{kg}$ recorded the highest egg weight $(11.64 \mathrm{~g})$ compared to other treated groups of MLM level as shown in (Table 2), which may be attributed to the decrease in feed intake and attributed to the biological function of medical plant components. Khodary et al.(1996) stated the efficiency of herbal edible plants and some plant seeds as natural tonic, restoratives, antibacterial and anti-parasitic drugs in improving the productive performance in poultry.

\section{Egg number and egg mass}

Results in (Table 2) indicate that egg number and egg mass during the whole experimental period recorded significantly $(P<0.05)$ among the experimental groups. It is worthy noting that egg number was higher in birds receiving 1.00 and $1.50 \%$ MLM compared to other experimental groups, this may be due to the differences in sexual maturity and attributed to the biological function of medical plant components. It is clear that supplemented of diet by $0.5,1.00$ or $1.50 \mathrm{~g} / \mathrm{kg}$ MLM increased egg number by $8.33,11.67$ or $11.67 \%$ than that of the control group, respectively.

Egg mass recorded maximum values for $1.00 \mathrm{~g} / \mathrm{kg}$ of MLM diet, while minimum values recoded by $0.50 \mathrm{~g} / \mathrm{kg}$ MLM level.

It is worthy noting that feeding quail on $0.5,1.0$ or $1.5 \%$ MLM resulted in $8.68,12.74$ and $12.45 \%$ higher in egg mass than that of the control group, respectively. However, the increase in egg mass with the 1 or $1.5 \mathrm{~g} / \mathrm{kg}$ of MLM level was expected in view of the increase in egg number and vice versa with the $0.5 \mathrm{~g} / \mathrm{kg}$ of MLM level.

\section{Feed intake and feed conversion Ratio}

On the basis of the whole experimental period there was significantly $(P<0.05)$ among the experimental groups for daily feed intake trait.

The experimental groups exhibited more feed intake compared to the control group. It is clear increasing MLM levels in the experimental diets increased that feed intake. The supplementation of with $0.5,1.0$ or $1.5 \mathrm{~g} / \mathrm{kg}$ of MLM increased feed intake by $1.86,3.10$ and $4.83 \%$ more than that of the control group, respectively.

This increase in feed intake may be due to improving the diet palatability. Natural feed additives had beneficial effect for stimulation and activity of digestive system by improving the diet palatability and enhancing 
appetite of poultry, thus increasing the amount of feed consumed (Namur et al., 1988).

The results of feed conversion ratio showed are significant increases in feed efficiency utilization by the MLM level in diet as compared to control group during the experimental period. Quail fed $1 \mathrm{~g} / \mathrm{kg}$ MLM during the experimental period recorded the best feed conversion.

In gradually, the data indicated that the feed conversion ratio of the group fed diets supplemented with MLM was improved compared to those of the control group.

The improvement in feed conversion ratio of $1.0 \mathrm{~g} / \mathrm{kg} \mathrm{MLM}$, may be due to its highest egg mass as compared to that of MLM levels. Such improvement may be attributed to the properties of these materials that could act not only as antibacterial, anti-protozoa and antifungal, also as antioxidants (Bradley, 1992; Leung and Foster, 1996).

Morality rate

No incidence of mortality occurred during the experimental period as well as no effects of MLM levels supplemented on the experimental diets. Eisenberg et al.(1993) indicated that herbal medicine is based on the premise that plants contain natural substances that can promote health and alleviate illness.

\section{Hatchability}

Results on hatchability percentage in the present study recorded a non-significant difference among groups (Table 2).

\section{Egg quality traits}

Data of egg quality indicate that relationship between levels of MLM and egg quality as shown in table (3).

Data on yolk percentage and shell thickness showed a nonsignificant difference among the experimental groups. On the other hand, egg weight, albumen, eggshell, yolk index, egg shape percentage were significantly varied $(P<0.05)$ among the experimental groups.

Table (3). Egg quality ( $\bar{X} \pm S E)$ as affected by Margoram leaves meal in laying quail diets.

\begin{tabular}{|c|c|c|c|c|c|}
\hline \multirow{2}{*}{ Items } & \multicolumn{4}{|c|}{ Levels of margoram leaves meal $(\mathrm{g} / \mathrm{kg})$} & \multirow[t]{2}{*}{ Sig } \\
\hline & Control (0) & 0.5 & 1.00 & 1.50 & \\
\hline Egg weight (g) & $11.45+0.07^{b}$ & $11.56 \pm 0.09^{\mathrm{ab}}$ & $11.60 \pm 0.11^{\mathrm{a}}$ & $11.59+0.19^{\mathrm{a}}$ & * \\
\hline Yolk \% & $31.06+0.07$ & $31.12+0.09$ & $31.30 \pm 0.16$ & $31.35 \pm 0.11$ & n.s \\
\hline Albumen \% & $55.25 \pm 0.09^{a}$ & $55.10 \pm 0.09^{a}$ & $54.79 \pm 0.14^{\mathrm{ab}}$ & $54.58 \pm 0.10^{\mathrm{b}}$ & * \\
\hline Egg shell \% & $13.23 \pm 0.02^{b}$ & $13.35 \pm 0.05^{\mathrm{ab}}$ & $13.81 \pm 0.07^{a}$ & $14.01 \pm 0.90^{\mathrm{a}}$ & * \\
\hline yolk index \% & $48.74 \pm 1.20^{a}$ & $48.94 \pm 1.30^{\mathrm{a}}$ & $47.55 \pm 1.25^{\mathrm{ab}}$ & $46.76 \pm 1.61^{\mathrm{b}}$ & * \\
\hline Egg shape \% & $78.18 \pm 0.04^{b}$ & $78.55 \pm 0.03^{\mathrm{ab}}$ & $79.62 \pm 0.02^{\mathrm{a}}$ & $80.11 \pm 0.02^{\mathrm{a}}$ & * \\
\hline Shell thickness (mm) & $0.240 \pm 0.04$ & $0.241 \pm 0.05$ & $0.242 \pm 0.06$ & $0.245 \pm 0.04$ & n.s \\
\hline
\end{tabular}

\section{Digestibility and nutritive values of the experimental diets}

Digestion coefficients of nutrients content as affected by the different levels of MLM are illustrated in (Table 4). Results indicate a significant 
$(P<0.05)$ differences among groups by the increasing of MLM in the experimental diets. It was clearly noted that the best value of CP digestibility was obtained for quail fed diets supplemented with the $1.5 \mathrm{~g} / \mathrm{kg} \mathrm{MLM}$, followed by those fed $1.0 \mathrm{~g} / \mathrm{kg}$, while the lowest value was observed with those fed the control diet.

In general, there was a tendency for increase in the digestion coefficients of OM, CF, EE and NFE for the same of the experimental diets were accepted when compared with the control diet.

Table (4). Digestibility coefficients and nutritive values ( $\bar{X} \pm S E)$ of the experimental diets as affected by levels of Margoram leaves meal

\begin{tabular}{|c|c|c|c|c|c|}
\hline & \multicolumn{4}{|c|}{ Levels of margoram leaves meal $(\mathrm{g} / \mathrm{kg})$} & \multirow{2}{*}{ Sig } \\
\hline Items & Control (0) & 0.5 & 1.0 & 1.50 & \\
\hline \multicolumn{6}{|c|}{ Digestion coefficients $\%$} \\
\hline $\mathrm{OM}$ & $79.05+1.52^{b}$ & $79.84+1.22^{b}$ & $80.02+1.60^{a}$ & $80.75+1.41^{a}$ & * \\
\hline $\mathrm{CP}$ & $80.10+2.32^{b}$ & $81.52+1.38^{\mathrm{ab}}$ & $82.79+1.45^{a}$ & $83.96+1.60^{a}$ & * \\
\hline $\mathrm{CF}$ & $24.08 \pm 2.09^{b}$ & $24.72 \pm 1.85^{\mathrm{b}}$ & $26.16 \pm 1.63^{\mathrm{ab}}$ & $27.60 \pm 1.41^{\mathrm{a}}$ & * \\
\hline $\mathrm{EE}$ & $85.96+1.02^{b}$ & $87.14 \pm 0.81^{\mathrm{ab}}$ & $87.94 \pm 0.72^{a}$ & $88.79 \pm 0.85^{a}$ & * \\
\hline NFE & $86.02+1.10^{\mathrm{b}}$ & $88.29+0.40^{\mathrm{ab}}$ & $88.69+1.03^{a}$ & $89.22+1.21^{a}$ & * \\
\hline \multicolumn{6}{|c|}{ Nutritive values } \\
\hline DCP\% & $16.22+0.24^{b}$ & $16.51+0.12^{\mathrm{ab}}$ & $16.76+0.20^{a}$ & $17.00+0.25^{a}$ & * \\
\hline TDN\% & $65.27+1.21^{b}$ & $66.75+1.01^{a b}$ & $67.32+1.33^{a}$ & $67.93+1.62^{a}$ & * \\
\hline $\mathrm{ME}(\mathrm{kcal} / \mathrm{kg})$ & $2746 \pm 30.21^{b}$ & $2808+29.11^{\mathrm{ab}}$ & $2831 \pm 30.17^{a}$ & $2856+35.80^{a}$ & * \\
\hline
\end{tabular}

a,b: Means within the same row showing different letters are significantly different. Sig.=Significance, ${ }^{*}=(P<0.05)$.

Similar trend was observed for the nutritive values of the tested diets in terms of digestible crude protein (DCP\%), total digestible nutrients (TDN\%) and $M E(\mathrm{kcal} / \mathrm{kg})$, which differed significantly $(P<0.05)$ increased with increasing MLM up to $1.50 \mathrm{~g} / \mathrm{kg}$ level.

In generally, the results showed that improvement of digestibility coefficients of nutrients and nutritive values significantly $(P<0.05)$ increased with increasing MLM level. It is of great importance to note that the results of the digestion trial were coincided generally with the positive response in productive performance and feed utilization of quail birds, comparative to the control diet.

These results were in agreement with Abd EL-Latif et al,(2003) who indicated that, addition of medicinal herbal had a significant effect on improving digestibilities coefficient of nutrients.

Adding herbal medicinal plants to the diet increased $(P<0.05)$ both T3 and T4 plasma concentration, the consistency of body gain and feed intake trends and thyroid activity asserted the biological role for herbal medicinal plants in activities metabolic functions and biosynthesis of hormones (Abd ElLatif et al., 2002). El-Husseiny et al.(2000) reported that increased thyroxin concentration, significant positive effect on the values of $C P, E E, C F$, NFE digestibility and metabolizable energy. 
Abd EI - Galil, $k$.

\section{Economical evaluation.}

The present results indicated that the diet containing $1 \mathrm{~g} / \mathrm{kg}$ Margoram leaves meal (MLM) as a feed additive was highest Net revenue and economic efficiency compared to the other experimental groups as shown in table (5) and fig.(1) this may be related to increase improvement of feed conversion ratio. It was noticed that the control diet gave the lowest Net revenue and economic efficiency.

The best relative economic efficiency was detected with $1 \mathrm{~g} / \mathrm{kg} \mathrm{MLM}$ being $110.14 \%$ followed by those fed $0.5 \mathrm{~g} / \mathrm{kg} \mathrm{MLM}$, respectively when compared with the control group.

Table (5): Economical evaluation of quail as affected by dietary MLM.

\begin{tabular}{|l|c|c|c|c|}
\hline \multirow{2}{*}{ Item } & \multirow{2}{*}{ Control } & \multicolumn{3}{c|}{ Levels of MLM (g/kg) } \\
\cline { 3 - 5 } & & $\mathbf{0 . 5 0}$ & $\mathbf{1 . 0 0}$ & $\mathbf{1 . 5 0}$ \\
\hline Feed conversion ratio & 4.20 & 3.93 & 3.78 & 3.91 \\
\hline Cost of kg feed (L.E) & 1.350 & 1.357 & 1.364 & 1.371 \\
\hline Feed cost of kg egg (L.E) & 5.670 & 5.333 & 5.156 & 5.361 \\
\hline Selling price of one kg egg (L.E) & 15.00 & 15.00 & 15.00 & 15.00 \\
\hline Net revenue (L.E) & 9.330 & 9.667 & 9.844 & 9.639 \\
\hline Economic efficiency & 164.55 & 181.27 & 190.92 & 179.80 \\
\hline Relative economic efficiency & 100 & 110.16 & 107.83 & 101.55 \\
\hline
\end{tabular}
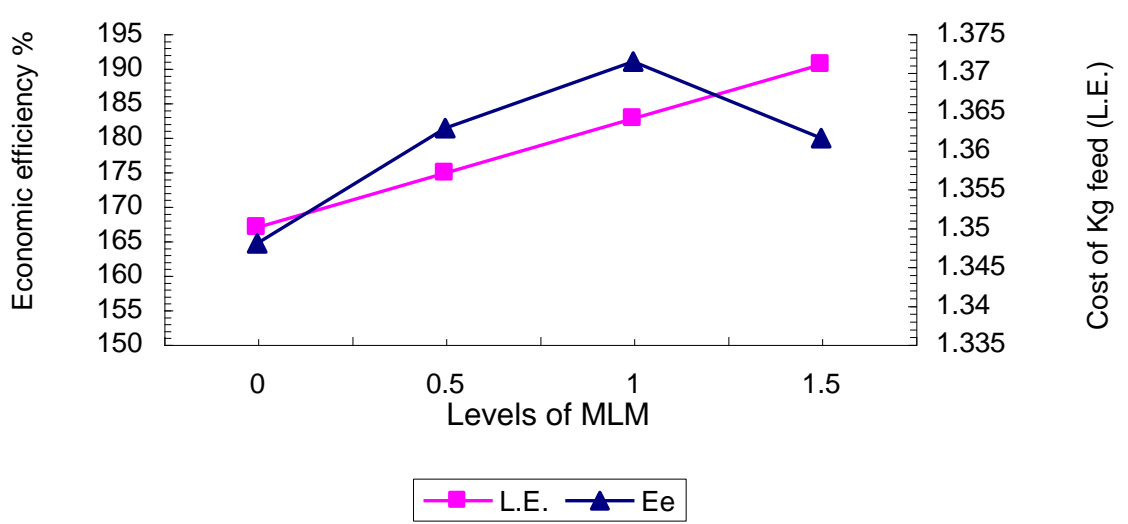

Fig.(1) Economic efficiency (Ee) and cost of $\mathrm{Kg}$ feed (L.E) of differnt levels of MLM by laying quail

\section{CONCLUSION}

It could be concluded that used of feed additives such as Margoram leaves meal (medicinal herbs) for laying Japanese quail diets at a level of $1 \mathrm{~g} / \mathrm{kg}$ diet improved the productive performance and economical efficiency. 


\section{REFERENCES}

Abaza, L. M. (2001). The use of some medicinal plants as feed additives in broiler diets. Ph. D. Thesis Fac. of Agric., Alexandria Univ., Egypt.

Abd EL-Latif,S. A.; Faten A. Ahamed and A.M.EL-Kaiaty (2002). Effect of feeding dietary thyme black cumin,dianthus and fennel on peroductive and some metabolic responses of growing japanese quail. Egypt.Poult. Sci., 22(1):109-125.

Abd EL-Latif, S .A.; A.T.EL-Yamanyand and Eman A.F.Eldaly (2003). Evaluation of using qifferent levels and sources of medical herbs in growing japanese quail diets. Egypt.J.Nutr..and Feeds 6 (Specicallssue):219-220.

Abdel-Aal, E.S.M. and R.S.Attia (1993).Characterization of black cumin (Nigella sativa) seed. 1-Chemical composition and lipids. Alexandria of Sci., Exchange, 14:467-482.

Abou-Raya, A.K. and A.G. Galal (1971). Evaluation of poultry feeds in digestion trials with reference to some factors involved. Egypt. J. of Anim., 11 (1): 207-221.

A.O.A.C., Association of Official Analytical Chemists (1990). In "Official Methods of Analysis", $15^{\text {th }}$.ed., Washington, USA.

Azcan, N ; M. Kara; B.Demirci and K.H.Baser (2004). Fatty acids of the seeds of Origanum onites, L. and O. vulgare. J. of Lipids, 39(5):487-490.

Bachman, S. E. and M. M. Mashaly (1986). Relationship between circulating thyroid hormone and Humoral immunity in immature male chickens. Develop. Comp. Immunol., 10: 395-403.

Boulos, L. (1983). Medicinal plants of north Africa reference publication. Inc. Proc., 2nd Cong. Fac. Vet. Med. Cairo, Univ., Cairo, Egypt.

Bradley, P.R. (1992). British Herbal Compendium, Vol.1, Bournemouth: British Herbal Medicine Association.

Duncan, D. B. (1955). The multiple range and F- tests. Biometrics, 11: 1-42.

Dadaliogl, L. and G,A. Evrendilek (2004). Chemical compositions and antibacterial effects of essential oils of Turkish oregano (Origanum minutiflorum), bay laurel (Laurus nobilis), Spanish lavender (Lavandula stoechas L.) and fennel (Foeniculum vulgare) on common foodborne pathogens. . Agric. Food Chem, 52(26):8255-8260.

Eisenberg, D. M.; R.C. Kessler; C.Foster ; F.E. Norlock; D. R. Calkins and T. L. Delbanco (1993). Unconventional medicine in the United States. Preference, costs and patterns of use. J. Med, 328:246-252.

El-Hindawy, M.M; M.L. Tawfeek and S.H. Osman (1996). Effect of some biological feed additives for different periods on performance of broiler chick. Zagazig. J. Agric. Res., 23 (5): 773-783.

El-Husseiny, O; Sohir A. Arafa; Samia; M. Hashish and A.H.H. Madian (2000) response of broiler performance to triiodotyrosine (T3) thyroxine (T4), iodocasein and thiouracil supplemented diets. Egypt. Poult. Sci., 20 (2): 347-371. 
El-Ashmawy, L. M.; A.F. El-Nahas and O.M.Salama (2005).Protective effect of volatile oil, alcoholic and aqueous extracts of Origanum majorana on lead acetate toxicity in mice. Basic Clin. Phamacol Toxicol 97(4): :238243

Gill, C. (1999). More Science be hind 'Botanical: herbs and plant extracts as growth enhances. Feed international (4): 20-23.

Ibrahim, M. R.; S. A. Abd El-Latif and A. T. El-Yamany (1998). Effect of adding some natural growth promoters to broiler chicks diets on growth performance, digestibility and some metabolic functions. J. Agric. Sci.," Mansoura Univ., 32(3):1029- 1037.

Jakobsen, P.E.; S.G. Kirsten and H. Niclsen (1960). Fredjelighed frogmed fierbrae. Digestibility trails with poultry "Bereting fra for sogslabortoriat, Kabenhaven, 56: 1-34.

Khodary,R.M.; M.H. El-Ezzawy and I.R. Hamdy(1996). Effect of Niega/la sattive on egg production, hatchability percentage and some biochemical values in laying hens with reference to fertility in cockerles.Proc.of th Sci.,Vet. Med., Assuit Univ., Egypt,17-19.

Hazzit, M.; A.Baaliouamer; M.L. Faleiro and M.G. Miguel (2006). Composition of the essential oils of Thymus and Origanum species from Algeria and their antioxidant and antimicrobial activities. J. Agric. Food Chem., 54(17):6314-6321.

Leung, A.Y.and S. Foster (1996). Encyclopedia of Common Natural Ingredients used in Food, Drugs and Cosmetics, 2nd Ed. New York: John Wiley\& Sons, Inc.

Namur, A. P.; J Morel and H. Bichek (1988). Compound animal feed and feed additives. In Deboer, F., H. Bichel, Eds. Livestock feed resources and feed evaluation in Europe. Elsevier. Sci., Published, Amsterdam.

NRC., National Research Council (1994).Nutrient Requirements of Poultry. $9^{\text {th }}$ Revised ed. National Academy Press, Washington, D.C.USA.

Osman, S.M.H. (1996). Responses of broiler chicks for some dietary supplementation M.Sc. Thesis Fac., of Agric. Zagazig Univ., Egypt.

SAS (1996). Statistical analysis system User's Guide. SAS institute, Gary, North Carolina.

Souad El-Gengaihi, H.S. Taha and A.M. Kamel (2006). In vivo and in vitro comparative studies of Origanum species. J. of Food, Agric., and Environment, 4 (3): 127-134.

Titus, H.W. and J.C. Fritz (1971). In "The scientific feeding of chickens". The interstate printers and Publishers, Inc., Danville, Illinois, USA. 


\section{تأثير بعض الإضافات الغذائية على أداء السمان الياباني البياض:

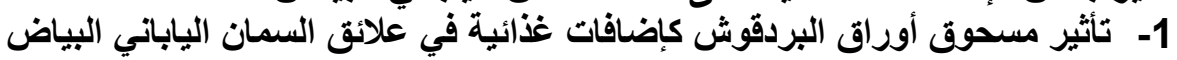 خالد عبد الجليل قسم تفذية الحيوان والدواجن - مركز بحوث الصحراء ـ المطريةـ القاهرة- مصر}

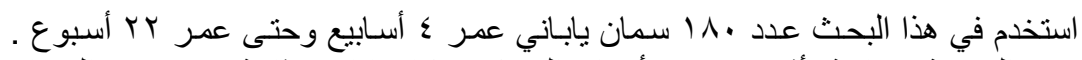

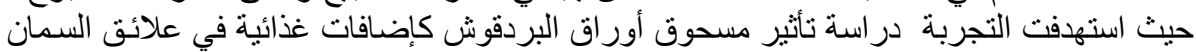

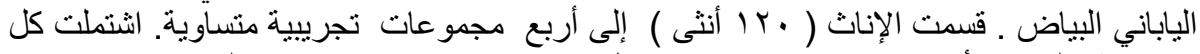

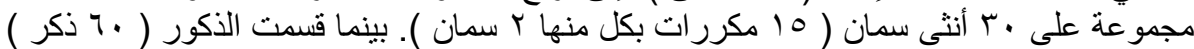

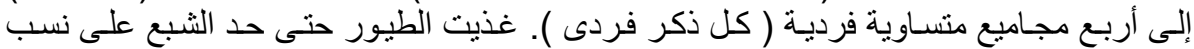

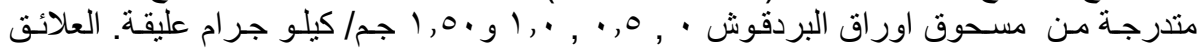

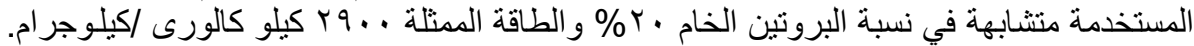

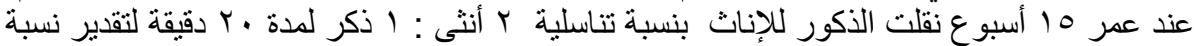

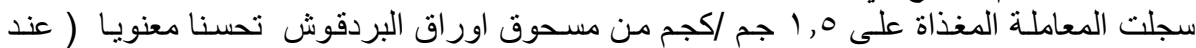

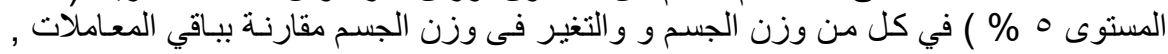
بينما سجلت مجموعة المقارنة اكثر القيم انخفاضا.

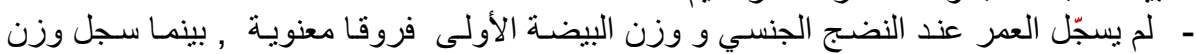

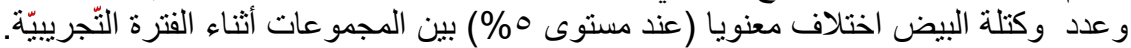

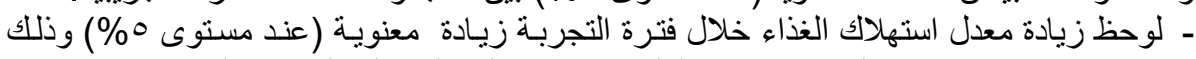

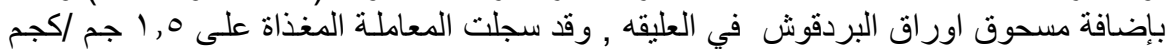

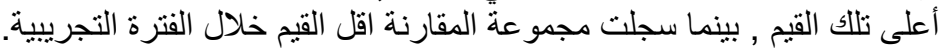

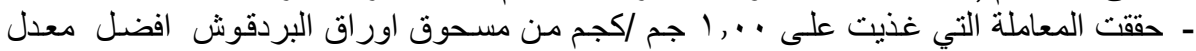

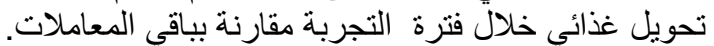

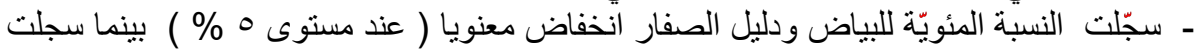

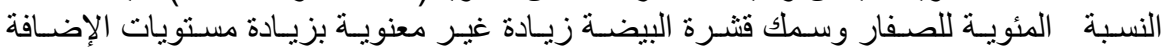

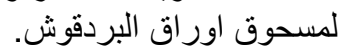

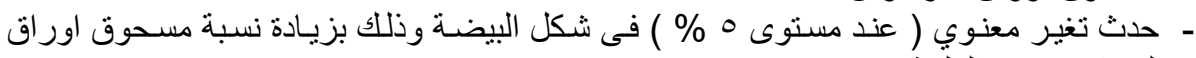
البردقوش فى العليقة.

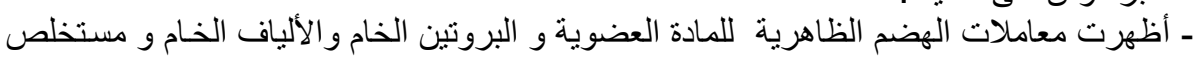

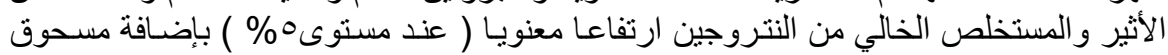

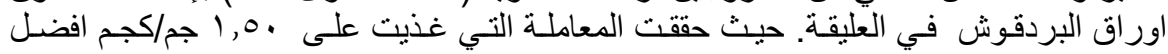

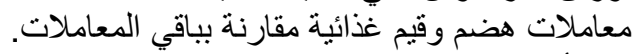

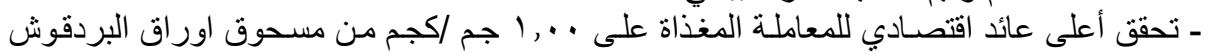

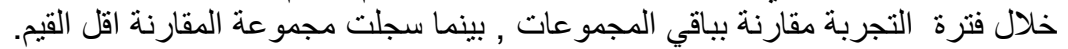

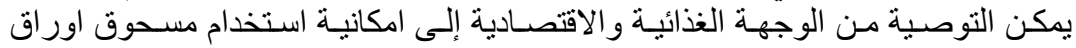

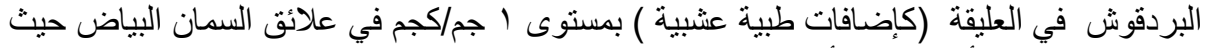
سجل افضل معدل أداء إنتاج وأعلى كفاءة اقتصادية. 